\title{
Multifunctional Activities of Green Tea Catechins in Neuroprotection
}

\author{
Modulation of Cell Survival Genes, Iron-Dependent Oxidative Stress and PKC \\ Signaling Pathway
}

\author{
Silvia A. Mandel Yael Avramovich-Tirosh Lydia Reznichenko Hailin Zheng \\ Orly Weinreb Tamar Amit Moussa B.H. Youdim
}

Eve Topf and USA National Parkinson Foundation Centers of Excellence for Neurodegenerative Diseases Research, Technion-Faculty of Medicine, Haifa, Israel

\section{Key Words \\ (-)-Epigallocatechin-3-gallate · Neurorescue • Neurodegeneration - Neuroprotection · Parkinson's disease - Neurite outgrowth - Green tea catechins • Iron chelation $\cdot$ Cell signaling $\cdot$ Protein kinase C}

\begin{abstract}
Many lines of evidence suggest that oxidative stress resulting in reactive oxygen species (ROS) generation and inflammation play a pivotal role in the age-associated cognitive decline and neuronal loss in neurodegenerative diseases including Alzheimer's (AD), Parkinson's (PD) and Huntington's diseases. One cardinal chemical pathology observed in these disorders is the accumulation of iron at sites where the neurons die. The buildup of an iron gradient in conjunction with ROS (superoxide, hydroxyl radical and nitric oxide) are thought to constitute a major trigger in neuronal toxicity and demise in all these diseases. Thus, promising future treatment of neurodegenerative diseases and aging depends on availability of effective brain permeable, iron-chelatable/radical scavenger neuroprotective drugs that would prevent the progression of neurodegeneration. Tea flavonoids (catechins) have been reported to possess potent ironchelating, radical-scavenging and anti-inflammatory ac-
\end{abstract}

tivities and to protect neuronal death in a wide array of cellular and animal models of neurological diseases. Recent studies have indicated that in addition to the known antioxidant activity of catechins, other mechanisms such as modulation of signal transduction pathways, cell survival/death genes and mitochondrial function, contribute significantly to the induction of cell viability. This review will focus on the multifunctional properties of green tea and its major component (-)-epigallocatechin3-gallate (EGCG) and their ability to induce neuroprotection and neurorescue in vitro and in vivo. In particular, their transitional metal (iron and copper) chelating property and inhibition of oxidative stress.

Copyright $\subset 2005$ S. Karger AG, Basel

\section{Introduction}

Polyphenols are natural substances present in beverages obtained from plants, fruits and vegetables such as olive oil, red wine and tea. Flavonoids are the largest group of polyphenols, which include the subclasses of flavones, isoflavones, flavanols, flavans and flavonols [1]. Several prototypes of these groups have been shown to promote a number of physiological benefits, especially in cognitive function and memory impairment. Fresh tea

\section{KARGER}

Fax +4161306 1234 E-Mail karger@karger.ch www.karger.com
(C) 2005 S. Karger AG, Basel

1424-862X/05/0142-0046\$22.00/0

Accessible online at:

www.karger.com/nsg
Prof. M.B.H. Youdim

Eve Topf and USA National Parkinson Foundation Centers of Excellence for

Neurodegenerative Diseases Research, Technion-Faculty of Medicine

POB 9697, 31096 Haifa (Israel)

Tel. +972 4 8295290, Fax +972 48513145 , E-Mail Youdim@Tx.Technion.ac.il 
(Camellia sinensis) leaves contain a high amount of catechins, a group of flavonoids or flavanols, known to constitute $30-45 \%$ of the solid green tea extract $[2,3]$. The favorable properties ascribed to tea consumption are believed to rely on its bioactive components, catechins and their derivatives, demonstrated to act directly as radical scavengers and exert indirect antioxidant effects through activation of transcription factors and antioxidant enzymes [for reviews, see 4,5 ]. The most abundant polyphenolic compound is EGCG, thought to contribute to the beneficial effects attributed to green tea, such as its anticancer, cardiovascular function improvement and antioxidant anti-inflammatory properties. Indeed, a number of epidemiological studies have shown that phenolic compounds reduce the risk of coronary heart disease, possibly via their anti-inflammatory effects, including inhibition of adhesion molecule and cytokine expression and augmentation of endothelial nitric oxide release [6]. Relative antioxidant activities among tea catechins have been found to be EGCG = (-)-epicatechin-3-gallate $($ ECG) $>(-)$-epigallocatechin $($ EGC) $>(-)$-epicatechin (EC) [7]. EGCG accounts for more than $10 \%$ of the extract dry weight (30-130 mg per cup of tea) followed by EGC $>$ EC $\geq$ ECG [2]. In addition to their radical scavenging action, green tea catechins possess well-established metal-chelating properties. Structurally important features defining their chelating potential are the $3^{\prime}, 4^{\prime}$-dihydroxyl group in the B ring [8] as well as the gallate group $[9,10]$, which may neutralize ferric iron to form redoxinactive iron, thereby protecting cells against oxidative damage [11]. However, a wealth of data is accumulating and indicating that the antioxidant/metal chelating attributes of the catechin polyphenols are unlikely to be the sole explanation for their neuroprotective and neurorescue capacity. Thus, catechin polyphenols were found to invoke a wide spectrum of different mechanisms of action responsible for cell survival [for our recent reviews, see 12,13$]$.

There is evidence that polyphenol metabolites and their parent compounds have access to the brain. Studies with radioactively labeled EGCG in mouse or chemiluminescence-based detection of EGCG in rats demonstrated its incorporation into brain, as well as in various organs including kidney, heart, liver, spleen and pancreas $[14,15]$. Furthermore, it has been shown that the methylated and glucuronidated derivatives of epicatechin are both detected in rat brain following oral administration [16].

Significant body of evidence support the hypothesis that brain iron dysregulation and oxidative stress (OS), resulting in ROS generation from $\mathrm{H}_{2} \mathrm{O}_{2}$ and inflammatory processes, trigger a cascade of events leading to apoptotic/necrotic cell death in neurodegenerative disorders, such as Parkinson's (PD), Alzheimer's (AD) and Huntington's diseases and amyotrophic lateral sclerosis (ALS) [17]. There is also evidence for increased expression of apoptotic proteins (for review see [18]), as well as mitochondria (complex I) and ubiquitin-proteasome system (UPS) dysfunction, which may lead to breakdown of energy metabolism and consecutive intraneuronal calcium overload [19-22]. Thus, neurodegeneration appears to be multifactorial, where a complex set of reactions lead to the demise of neurons. This assumption receives support from the familial (genetic) forms of neurodegenerative diseases identified in the last years, where mutations in genes, such as $\alpha$-synuclein, parkin and ubiquitin C-terminal hydrolase-L1 (UCHL-1) described in rare forms of hereditary PD [23], may lead to impairment in the activity of the UPS. More recently, recessive mutations in DJ-1 [24] and PINK1 (PTENinduced kinase 1) [25] were proposed to play a role in cellular response to OS, supporting a pathogenic role of ROS in the etiology of neurodegenerative diseases. Therefore, it is not surprising that antioxidants were the first drugs to be studied in an attempt to retard the progress of PD. Recently, coenzyme $\mathrm{Q}_{10}$, an intrinsic component of the mitochondrial respiratory chain acting as a bioenergizer and an antioxidant, was studied as a putative neuroprotective agent in PD. This double-blind, placebo-controlled pilot study demonstrated that high doses of coenzyme $\mathrm{Q}_{10}(1,200 \mathrm{mg} / \mathrm{d})$ were associated with a reduced rate of deterioration in motor function from baseline over the 16-month course of this trial [26].

Neuropathological and neurochemical studies on substantia nigra (SN) from PD brains and its animal models $[23,27,28]$ and our recent gene expression profiling of human SN pars compacta (pc) from PD patients [29] demonstrate the existence of a 'domino' cascade of neurotoxic events, which can be initiated at any point in the cascade. These series of events may act independently or cooperatively during the course of the disease, leading eventually to the demise of dopaminergic neurons. This has led to the current notion that drugs directed against a single target will be ineffective and rather a single drug or cocktail of drugs with pluripharmacological properties may be more suitable to be employed. According to this belief, green tea catechins well fulfill the requirements for a putative neuroprotective drug having diverse pharmacological activities. Thus, it is not surprising that they 
have attracted increasing interest as therapeutic cytoprotective agents for the treatment of neurodegenerative and other diseases.

In this article the state of the art of the diverse molecular mechanisms and cell signaling pathways participating in the neuroprotective action of green tea catechin polyphenols is reviewed. Particular attention has been paid to their iron-chelating properties with respect to the potential promise for iron chelation therapy, as a novel treatment for neurodegenerative diseases.

\section{Neuroprotective Effects of Catechins: Insights from in vivo and in vitro Studies}

There is a growing recognition that polyphenolic catechins exert a protective role in neurodegeneration. An experimental study conducted in N-methyl-4-phenyl1,2,3,6-tetrahydropyridine (MPTP) model of PD has shown that both green tea extract and EGCG effectively prevent mice striatal dopamine (DA) depletion and SN dopaminergic neuron loss [30]. The protection exerted by green tea polyphenols in vivo may involve direct scavenging of ROS and regulation of antioxidant protective enzymes. EGCG was found to elevate the activity of two major oxygen-radical species metabolizing enzymes, superoxide dismutase (SOD) and catalase in mice striatum [30]. This is supported by a previous finding where 1 month's administration of a catechin-containing antioxidant preparation increased SOD activity in the mitochondria fraction of striatum and midbrain and decreased thiobarbiturate reactive substance formation in the cortex and cerebellum of aged rats [31]. The structural catechol resemblance of EGCG may explain a recently reported inhibitory effect of green tea polyphenols on the DA presynaptic transporters. This inhibition lead to 1methyl-4-phenylpyridinium $\left(\mathrm{MPP}^{+}\right)$uptake blockade (because of competition for the vesicular transporter) thereby protecting DA-containing neurons against $\mathrm{MPP}^{(+)}$-induced injury [32]. In addition, EGCG greatly inhibited catechol-O-methyltransferase (COMT) activity in rat liver cytosol at a low $\mathrm{IC}_{50}$ concentration $(0.2 \mu M)$ [33]. This action may be of particular significance for PD patients, given that DA and related catecholamines are physiological substrates of COMT, thus its inhibition will result in increased DA in the synapse.

Green tea polyphenols have been also shown beneficial in animal models of cerebral ischemia: intraperitoneal injection of EGCG reduced hippocampal neuronal damage and brain edema caused by global [34] or unilateral
[35] cerebral ischemia in gerbils. Insights into the possible mechanism of neuroprotection by EGCG in the infarct area of ischemic rats, revealed that it acts by reducing iNOS expression, infiltration and peroxynitrite formation [36], by increasing endothelial and neuronal NOS and preservation of mitochondrial complex activity and integrity [37]. In this context, the decrease in the activity of the transcription factor signal transducer and activator of transcription-1 alpha (STAT-1alpha) by EGCG in ischemic rat cardiac myocytes may well account for the reduced mRNA levels of iNOS, a target of STAT-1 [38]. Other investigators have recently shown that EGCG reduced brain inflammation and neuronal damage in experimental autoimmune encephalomyelitis (EAE), when given at initiation or after the onset of EAE [39].

An extensive number of studies regarding neuroprotection by green tea flavonoids in cellular and animal models of neurodegenerative diseases are starting to accumulate. Hence, the flavonoid epicatechin was shown to attenuate the toxicity induced by oxidized low-density lipoprotein in mouse-derived striatal neurons [40] or fibroblasts [41] and to confer protection to primary culture of mesencephalic neurons challenged with 6-hydroxydopamine (6-OHDA) [42]. Recently, catechin was shown to reduce injury produced by hydrogen peroxide, 4-hydroxynonenal, rotenone and 6-OHDA in primary rat mesencephalic cultures, as shown by increases in cellular viability and $\left[{ }^{3} \mathrm{H}\right] \mathrm{DA}$ uptake [43]. Similarly, EGCG was reported to protect human neuroblastoma cells from damage induced by 6-OHDA and $\mathrm{MPP}^{+}$[44]. EGCG also protects primary hippocampal neurons [45] and rescues rat pheochromocytoma ( $\mathrm{PC12}$ ) cells from amyloid- $\beta$ peptide (A $\beta)$-induced toxicity [46]. More recently, EGCG was reported to exert a neurorescue activity in long-term serum-deprived PC12 cells and to promote neurite outgrowth, as manifested by the expression of a surrogate marker of cell differentiation, growth-associated protein GAP-43 (GAP-43) [47]. This could have important implications with regard to aging, $\mathrm{PD}$ and $\mathrm{AD}$, suggesting a potential therapeutic use of EGCG in regenerating injured neuronal cells.

\section{Neuroprotection and Neurotoxicity by Low and High Concentrations of Catechins and Other Flavonoids}

Studies from our and other laboratories have shown that green tea polyphenols display a concentration-dependent window of neuroprotective action: They protect 
at low micromolar concentrations, whereas they become pro-oxidant and pro-apoptotic when increasing the concentrations over 10-20 $\mu M[44,48]$. This bell-shaped pattern is typical of antioxidative drugs, such as vitamin C [49], R-apomorphine [50] and DA [51], being neuroprotective at low $(1-10 \mu M)$ concentrations, while having pro-oxidant/pro-toxic activity at higher $(10-50 \mu M)$ concentrations. The toxicity of not only green tea polyphenols, but also of several other flavonoids, is responsible for their antiproliferative and chemopreventive actions. The anticancer properties of polyphenols is attributed to the ability to inhibit phase I and induce phase II carcinogen metabolizing enzymes (in animals) that initiate carcinogenesis, inhibition of cell cycle progression effectors, promotion of ROS and nitrogen species (thereby collapsing the mitochondrial membrane potential), induction of p53 and apoptogenic factors and inactivation of protein kinases that contribute to survival-associated signal transduction [for extensive reviews see 5, 52, 53]. Since the present article applies to the mechanisms of neuroprotection by tea catechins, the literature regarding their anticarcinogenic or pro-apoptotic properties will not be reviewed.

\section{Mechanism of Neuroprotection by Green Tea Catechins}

\section{Cell Signaling Pathways}

Selective Activation of Protein Kinase C (PKC) in

Brain Neurons

PKC expression has been previously coupled with the preservation of cell survival and the formation and consolidation of different types of memory [54-56]. The induction of PKC activity in neurons is thought to be a prerequisite for neuroprotection against several exogenous insults. Indeed, PKC $\varepsilon$ activation after ischemic preconditioning or pharmacologic preconditioning (with PKC $\varepsilon, N M D A$, or A1AR agonists) was shown essential for neuroprotection against oxygen/glucose deprivation in organotypic slice cultures [57]. In accordance, activation of PKC by estrogen or by the grape flavonoid resveratrol, in rat cortical or hippocampal neurons, respectively, protects against $A \beta$ toxicity $[58,59]$. Also, we have recently shown that the anti-Parkinson/monoamine oxidase-B (MAO-B) inhibitor drug, rasagiline (Teva Pharmaceutical Industries) [60], prevented PC12 cell death induced by serum deprivation via PKC signaling cascade [61]. Similarly, we have reported that phosphorylative activation of PKC by EGCG is responsible for the protec- tive effects against 6-OHDA- and A $\beta$-induced cell death in SH-SY5Y and PC12 cells $[44,46]$ and for the neurorescue effect against long-term growth factors withdrawal in PC12 cells [47]. This is supported by the observation that EGCG could not overcome cell death under PKC pathway blockade, as determined both morphologically and by monitoring various apoptotic markers, suggesting that this cascade is essential for the neuronal protection and rescue effects of EGCG. Consistent with these findings, recent animal studies have shown that two weeks consumption of EGCG $(2 \mathrm{mg} / \mathrm{kg})$ led to a highly significant up-regulation of $\mathrm{PKC} \alpha$ isoform in mice striatum [62] and to a significant increase in PKC isoenzymes $\alpha$ and $\varepsilon$ in the membrane and cytosolic fractions of mice hippocampus [46]. The implication of PKC $\alpha$ in neuronal survival by EGCG is further demonstrated in vitro by the rapid translocation of $\mathrm{PKC} \alpha$ to the membrane compartment in PC12 cells, in response to EGCG (fig. 1). PKC $\alpha$ is a well-established neuron cell survival factor participating also in cell growth and differentiation [63, 64]. In support, a recent report shows that treatment of human cells with EGCG induces a specific translocation of PKC $\alpha$ to the membrane [65].

More direct evidence implicating PKC in EGCG mechanistic action has come from a recent study employing solid-state nuclear magnetic resonance, showing that EGCG interacts with the head group region of the phospholipids within lipid bilayers from liposomes [66]. The interaction pattern of EGCG in terms of rotational motion within the lipid bilayers was similar to that described for 12-O-tetradecanoylphorbol-13-acetate (TPA) [67], a phorbol ester. Phorbol esters are prototype activators of PKC, suggesting that direct interaction of green tea catechins with cell membranes may be sufficient for the rapid activation of PKC by EGCG previously reported by us [44]. The impact of EGCG on membrane fluidity may give rise to activation of other membrane-associated signaling pathways (e.g. G proteins), which can contribute as well to its protective action. This clearly needs to be examined.

Modulation of Other Signal Transduction Pathways and Intracellular Transducers

In addition to $\mathrm{PKC}$, other cell signaling pathways have been also implicated in the action of green tea catechins such as the mitogen-activated protein kinases (MAPKs) and phosphatidylinositide $3^{\prime}-\mathrm{OH}$ kinase (PI3K)/AKT signaling cascades. These cascades have been shown to play central functions in neuronal protection against a variety of extracellular insults and to be essential for neu- 


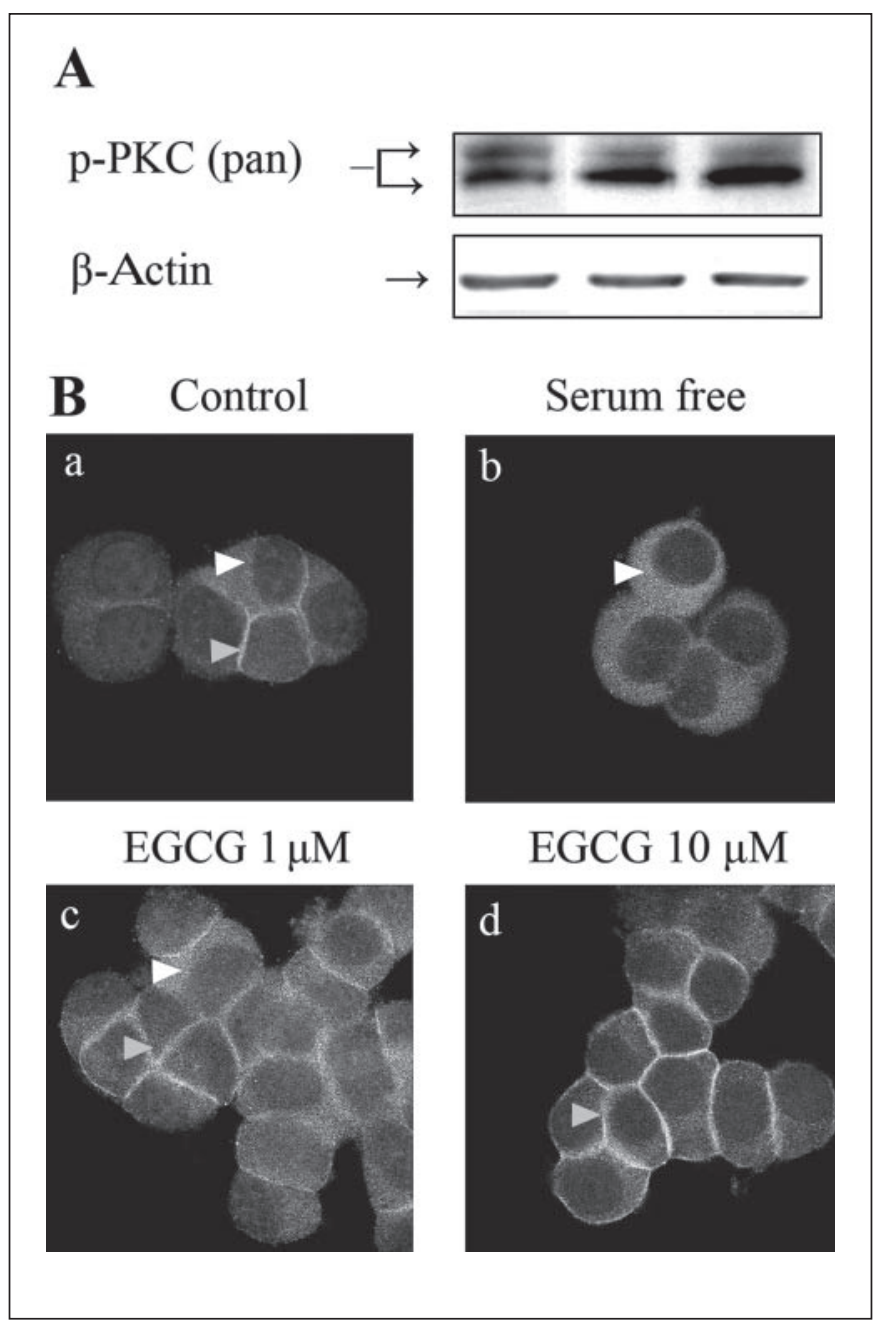

Fig. 1. $E G C G$ activates $p-P K C$ (pan) and induces a rapid activation of PKC $\alpha$ and translocation to the membrane. A Cell lysates from PC12 cells deprived of serum for $24 \mathrm{~h}$ before short-term (15 min) exposure to EGCG $(1-10 \mu M)$ were subjected to SDS-PAGE and Western blot, with p-PKC (pan) antibody. B Cultured PC12 cells grown with full serum (FS) support (control) were deprived of serum $(\mathrm{SF})$ for $24 \mathrm{~h}$ before short-term $(15 \mathrm{~min})$ exposure to EGCG $(1-10 \mu M)$. The cells were fixed and permeabilized for subcellular localization of $\mathrm{PKC} \alpha$ by confocal microscopy, using an isoenzymespecific antibody and FITC-conjugated secondary antibody (light areas). DRAQ5 stains nuclei (dark areas). Under FS conditions (control) PKC $\alpha$ is evenly confined to both plasma membrane (grey arrow) and cytosol (white arrow) (a). Upon serum withdrawal, PK$\mathrm{C} \alpha$ immunostaining is mosly cytosolic (b). In cells treated with EGCG PKC $\alpha$ is, in its majority $(1 \mu M)$, or entirely $(10 \mu M)$ localized to the cell membrane (arrows) (c, d). The images are representative fields from 3 independent experiments, all showing the same results. Taken from Reznichenko et al. [47]. ronal differentiation and survival [68-70]. OS seems to be a major stimulus for MAPK cascade, which might lead to cell survival/cell death [for review see 71]. Among the MAPKs the extracellular signal-regulated kinases (ERK1/2) are mainly activated by mitogen and growth factors [72], while p38 and c-jun-N-terminal kinase (JNK) respond to stress stimuli [73]. However, there have been reports where activation of ERK1/2 is thought to mediate neuronal injury such as in focal ischemia [74], in glutamate and oxidized-low-density-lipoprotein-induced toxicity $[40,75]$ and in cytotoxicity and activation of caspase-3 in the extraneuronal hepatoma HepG2 [76] and HeLa [77] cell lines, respectively. Increasing evidence shows that catechins can protect against neuronal cell death caused by exogenous OS-inducing agents through modulation of ERK activity [40, 44]. In this regard, a number of flavonoids and phenolic antioxidants, at their respective low protective concentrations, were demonstrated to activate the expression of some stress-response genes, such as phase II drug-metabolizing enzymes, glutathione-s-transferase and heme-oxygenase1 [77], likely via activation of the MAPK pathway [78].

More recently, additional signaling pathways, including PI3K/AKT, protein kinase A (PKA) and calcium, have been implicated in the neuroprotective action of catechin flavonoids. These studies have been conducted mainly in extra-neuronal tissue such as skin and heart. For example, topical application of EGCG induces proliferation of human normal epidermal keratinocytes through stimulation of ERK1/2 and AKT [79]. Other investigators reported a rapid activation of endothelial nitric oxide synthase after EGCG treatment by a process that involves PI3K, PKA and AKT in endothelial cells [80] and a decrease in iNOS expression via inactivation of STAT-1alpha in epithelial and colon cell lines [81]. Consistent with this, Townsend et al. [38] have recently reported that in cardiac myocytes EGCG protects against ischemia/reperfusion-induced apoptosis through a mechanism involving reduction of STAT-1 phosphorylation (inactivation) and of his downstream pro-apoptotic target gene, Fas. The discrepancy or divergence in the different signal pathway activation by EGCG may reflect differences in cell tissue (e.g. neuronal vs. peripheral), or in the downstream pathways being under the control of the different kinases, which may diverge into different responses, thereby providing cell function diversity.

\section{Anti-Apoptotic Activity}

EGCG has been reported to exert a biphasic mode of action as a function of concentration. The low micromo- 
lar concentrations are responsible for the anti-apoptotic/ neuroprotective actions of EGCG. This receives further recognition from an experiment employing customized cDNA microarray designed to clarify the molecular mechanisms involved in the cell survival action of EGCG [44]. The results revealed that a low EGCG concentration decreased the expression of pro-apoptotic genes bax, bad, caspases- 1 and 6, cyclin-dependent kinase inhibitor $p 21$, cell-cycle inhibitor gadd45, fas-ligand and tumor necrosis factor-related apoptosis-inducing ligand TRAIL, in SHSY5Y neuronal cells. The same group has reported recently that EGCG reduced the expression of several apoptogenic factors when given after long-term serum deprivation of PC12 cells [47]. These findings are supported by an in vivo study showing that two weeks oral consumption of EGCG $(2 \mathrm{mg} / \mathrm{kg})$ alone caused a complete disappearance of Bax immunoreactivity, specifically in the dopaminergic neurons of the SNpc [62] and counteracted the robust increase of Bax protein when administered before MPTP intoxication in the same area.

Bax alone, or in conjunction with the BH-3-only proteins (e.g. Bad, Bid, Bim, Noxa, Puma), can trigger the opening of the mitochondrial megachannel permeability transition pore (mPTP), or a specific channel in the outer mitochondrial membrane, both of which promote the fall in mitochondrial membrane potential, leading to cytochrome $c$ release and consequent cell death $[82,83]$. The decline in Bax expression by EGCG may favor the increase in the ratio of $\mathrm{Bcl}-2 / \mathrm{Bcl}-\mathrm{xL}$ to $\mathrm{Bax} / \mathrm{Bad}$ proteins, thereby contributing to mitochondrial stability and regulation of mPTP [84]. Protection of mitochondrial integrity is of major importance, especially in the case of postmitotic cells such as neurons and heart muscle cells, which are commonly not renewed. Thus, it is not surprising that one of the major neuroprotective strategies in $\mathrm{PD}, \mathrm{AD}$ and other neurodegenerative diseases, where increased OS, perturbed cellular energy and ion homeostasis have been implicated, includes pharmacological agents directed to specific mitochondrial targets. In this respect, Ginkgo biloba extract EGb 761 or its individual components were shown to protect mitochondria integrity by protecting against uncoupling of oxidative phosphorylation, thereby increasing ATP levels and by increasing the expression of the mitochondrial DNA-encoded COX III subunit of cytochrome oxidase [for review, see 85]. Flavonoids may also affect mitochondrial integrity by increasing GSH levels and preventing the influx of calcium, as previously reported $[86,87]$.

\section{Metal-Chelating Activity}

One cardinal feature of neurodegenerative diseases including AD, PD, Huntington's disease, ALS, Friedreich's ataxia, multiple sclerosis, and aceruloplasminemia is the appearance of excessive iron at degenerative neuronal sites [17]. The buildup of an iron gradient in conjunction with ROS (superoxide, hydroxyl radical and nitric oxide) are thought to constitute a major trigger in the demise in all theses diseases. Therefore, the chelation of free cellular ferric and ferrous ions by the different metal chelators make them potential agents to combat iron-induced generation of reactive oxygen radicals (by the Fenton and Haber-Weiss reactions) and aggregation of alpha $(\alpha)$ synuclein and $\mathrm{A} \beta$ in $\mathrm{PD}$ and $\mathrm{AD}$, respectively.

\section{Iron Chelation for AD}

A significant body of evidence point to an 'amyloid cascade' event in the pathogenesis of $\mathrm{AD}$, where amyloid precursor protein (APP) is processed to $A \beta$, by $\beta$ - and $\gamma$-secretases, which spontaneously self-aggregate in the presence of divalent metals $\left(\mathrm{Fe}^{2+}, \mathrm{Cu}^{2+}\right)$ into neurotoxic amyloid fibrils in the neocortex [88]. Iron was shown to promote both deposition of $\mathrm{A} \beta$ and $\mathrm{OS}$, which is associated with the plaques [89]. In addition, iron has taken center stage in $\mathrm{AD}$ as a consequence of the studies by Rogers and coworkers [90] who described the existence of an iron responsive element (IRE-type II) in the 5'UTR region of APP mRNA. APP is post-transcriptionally regulated by iron regulatory proteins (IRPs), which are labile iron pool-sensitive cytosolic RNA proteins binding specifically to the IRE located in the $5^{\prime}$ or $3^{\prime}$ untranslated regions of iron metabolism-associated mRNAs. Changes in iron status (iron overload or depletion) lead to compensating changes in the IRP/IRE system of translational control of iron homeostasis. For example, the APP 5'-UTR conferred translation was selectively down-regulated upon intracellular iron chelation, in a similar manner as the iron-storage protein ferritin, which also possesses an IRE in its 5'-UTR mRNA [90].

Iron removal has effects suggestive of inhibition of key enzymes or other metalloproteins, for instance in mimicking hypoxia, whereas many of the effects of iron overload may be the result of signaling associated with OS. Hypoxia and iron chelation have similar effects on genes regulated by the transcription factor hypoxia-inducible factor- $1 \alpha$ (HIF- $1 \alpha$ ), a master regulator orchestrating the coordinated induction of an array of hypoxia-sensitive genes [91]. The target genes of HIF are especially related to angiogenesis, cell proliferation/survival and glucose/ 


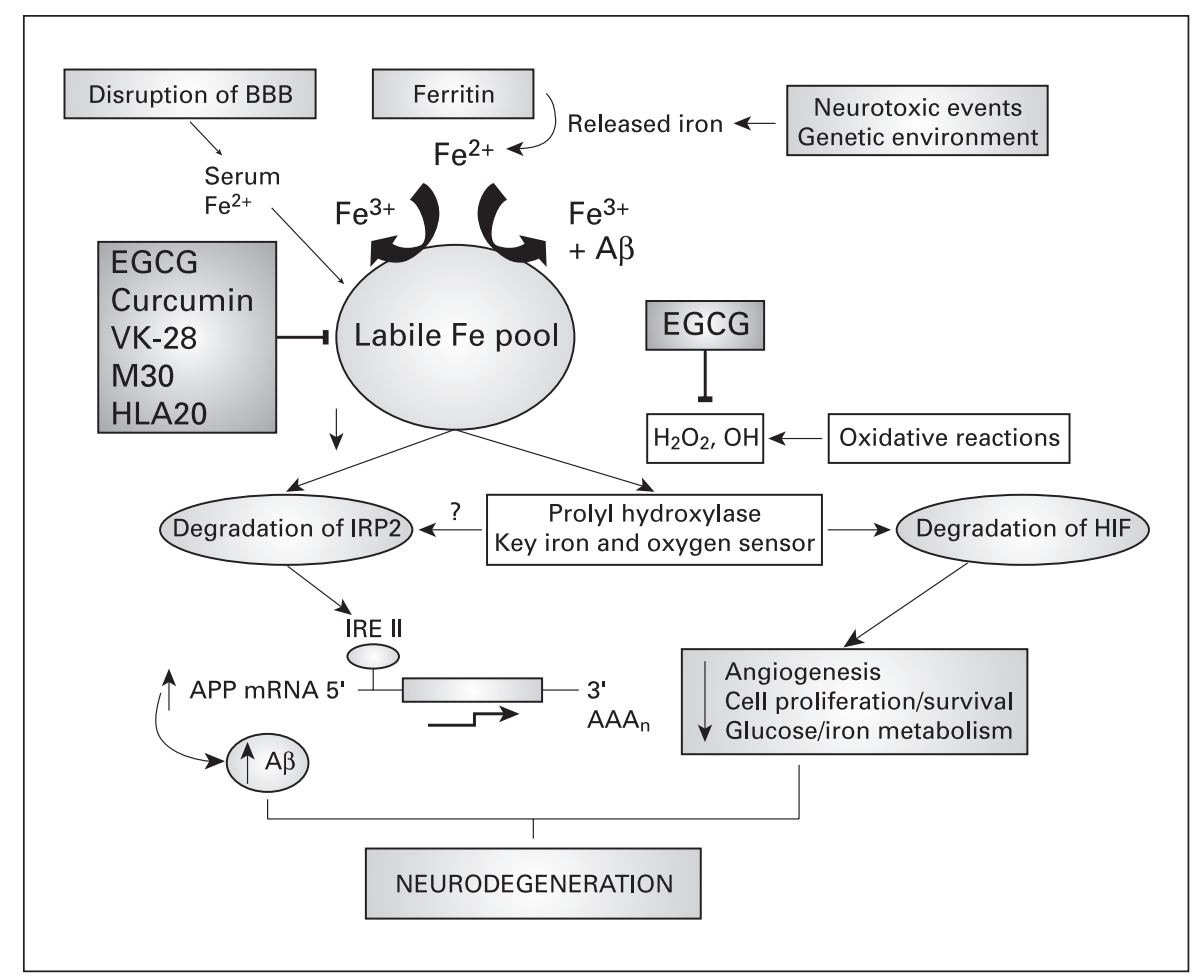

Fig. 2. Iron-induced neurodegeneration in $A D$ via transcriptional activation of APP mRNA. Neurodegeneration can result from abnormal serum iron transport to the neurons because a disruption in the blood-brain barrier (BBB) or from release from its storage protein ferritin, thereby increasing the free-labile iron pool (ionic iron). Labile iron can increase the production of amyloid precursor protein (APP) by down-regulating the activities of iron regulatory proteins (IRP1 and IRP2, inactivation and proteasomal degradation, respectively), thereby promoting the translation of APP mRNA from its 5'-UTR type II. Ionic iron may also cause aggregation of amyloid- $\beta$ peptide $(A \beta)$ to form toxic aggregates, which, in turn, can initiate $\mathrm{OH}^{\bullet}$ generation, causing oxidative stress (OS). Increased iron and OS may activate the prolyl hydroxylase enzymes which are key iron and oxygen sensors, leading to proteasomal-mediated degradation of the transcription factor hypoxia-inducible factor $1 \alpha$, a master regulator orchestrating the coordinated induction of a wide array of survival genes. It has been also suggested that IRP2 can be a substrate for prolyl hydroxylase. Neuroprotective agents that can be used to prevent iron-induced neurodegeneration include M30 and HLA20 (bifunctional iron chelator-MAO inhibitors), VK-28, EGCG and curcumin (iron chelators). For a more detailed explanation, read text. iron metabolism [92]. The mechanism of HIF-1 $\alpha$ activation by iron chelation is not well understood. Fe(II)/2oxoglutarate-dependent dioxygenases have been identified that hydroxylate critical proline and asparagine residues in HIF and upon high oxygen levels and iron overload, target HIF for degradation [93]. Thus, these prolyl hydroxylase enzymes act as key iron and oxygen sensors. This may explain the decrease in cell survival genes described in neurodegenerative diseases such as phosphofructokinase and the angiogenic factor VEGF, both regulated by the HIF proteins [94]. Interestingly, the free iron-induced proteasomal-mediated degradation of IRP2 involves also activation a prolyl hydroxylase and is inhibited by iron chelators [95, 96]. Thus, it is possible that IRP2 is a substrate for this enzyme, in a similar way as HIF, signaling it for protein degradation. This suggests a convergence of both iron and OS to a common pathway triggering the neurotoxic degenerative cascade (for a detailed explanation, see fig. 2).

The involvement of metals in the plaques of $\mathrm{AD}$ patients and the presence of an IRE in the unstranslated region of APP mRNA, have encouraged the development of iron chelators as a major new therapeutic strategy for the treatment of $\mathrm{AD}$. In fact, intramuscular administration of the prototype iron chelator desferrioxamine (DFO) slowed the clinical progression of AD dementia [97], and some success has also been achieved with another metal-complexing agent, clioquinol [98]. However, clioquinol is highly toxic [99] and DFO has poor penetration across the blood-brain barrier [17]. 


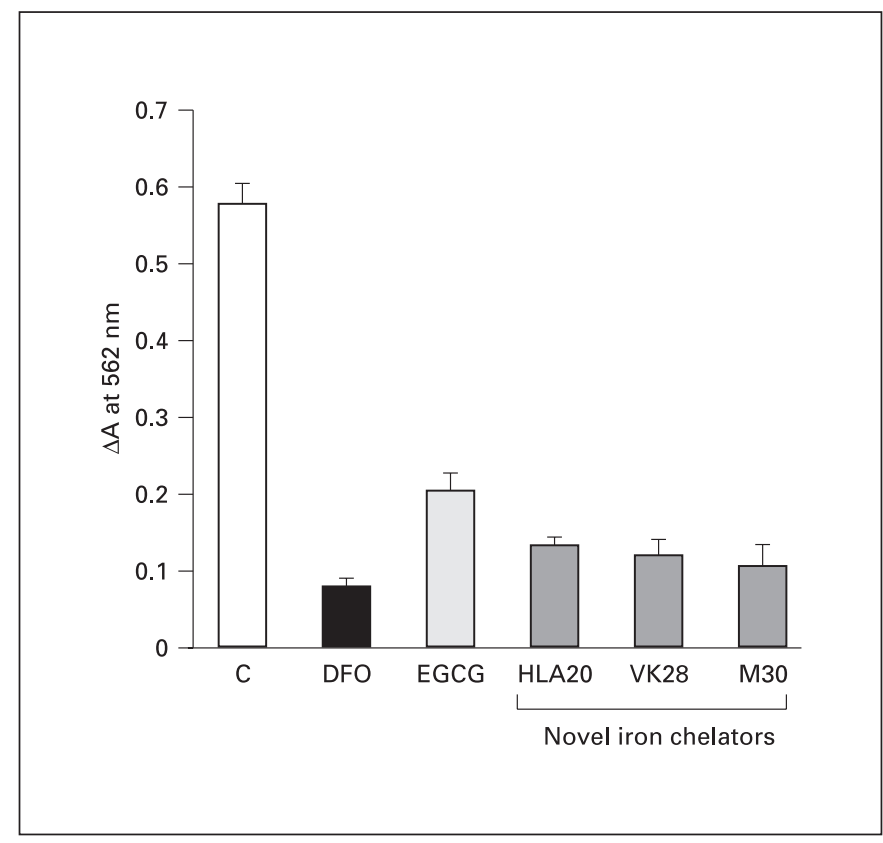

Fig. 3. Comparison of the $\mathrm{Fe}^{2+}$-chelating potency of EGCG to other iron chelators. The metal-binding capacity of EGCG was compared to that of DFO and the novel iron chelators VK28, HLA20 and M30, by assessing their ability to compete with ferrozine for the ferrous ions, resulting in decrease in the absorbance at $562 \mathrm{~nm}$. Ferrozine can quantitatively react with $\mathrm{Fe}^{2+}$ to form $\mathrm{Fe}^{2+}$-ferrozine complex with a strong absorbance at $562 \mathrm{~nm}$. In the presence of other chelating agents, the complex formation is disrupted with the result that the absorbance at $562 \mathrm{~nm}$ is decreased. $0.1 \mathrm{~m} M$ of drug was mixed with $0.1 \mathrm{~m} M$ ferrozine in $5 \%$ ammonium acetate $(\mathrm{pH}$ 7) followed by the addition of $0.02 \mathrm{mMFeSO}$. After $2 \mathrm{~h}$ incubation, the absorbance (at $562 \mathrm{~nm}$ ) of resulting solutions was read. Considering that the purpose of this assay was to evaluate the ability of drugs to compete with the iron indicator ferrozine, drugs and ferrozine were used at equal concentrations. Chelating effect of drug on $\mathrm{Fe}^{2+}$ was calculated as follows: Chelating effect $(\%)=[1-($ absorbance of sample at $562 \mathrm{~nm}) /($ absorbance of control at $562 \mathrm{~nm})] \times 100$. The order of chelating potency for complexing $\mathrm{Fe}^{2+}$ in solution is Desferal (DFO) $>\mathrm{M} 30 \geq \mathrm{VK} 28 \geq \mathrm{HLA} 20>$ EGCG.

A possible novel promising therapeutic approach for treating AD, PD and ALS with non-toxic, brain permeable metal chelators could be the use of the naturally occurring polyphenols, such as EGCG and curcumin, which by being of natural origin may not exert toxic side effects inherent to synthetic drugs. Both compounds have wellcharacterized antioxidant, metal (iron and copper) chelating and anti-inflammatory activities [12, 100] and have been demonstrated to exert neuroprotective activity against a variety of neurotoxic insults, as well as to regulate APP processing and $A \beta$ burden in cell culture and in vivo $[12,101]$. Our recent studies have shown that prolonged administration of EGCG to mice induced a reduction in holoAPP levels in the hippocampus [46]. Indeed, this effect may be related to the iron-chelating properties of EGCG, leading to a decrease in the free-iron pool. This in turn results in the suppression of APP mRNA translation by targeting the IRE-II sequences in the APP 5'-UTR [90], as was recently shown for DFO and the bifunctional amyloid-binding/metal-chelating drug XH1 [102] (fig. 2).

The concept of metal chelation as a neuroprotective strategy has led us to the development of non-toxic, lipophilic, brain-permeable iron chelators for progressive neurodegenerative diseases [103]. Compounds such as VK-28 (Varinel) [104] and the multifunctional iron chelators HLA20 and M30 [105, 106], which possess the propargylamine MAO inhibitory and neuroprotective moiety of rasagiline, display good cell permeability and are protective against 6-OHDA toxicity in differentiated $\mathrm{P} 19$ cells [107]. Comparative analysis of the $\mathrm{Fe}^{2+}$-chelating potency of EGCG, the prototype DFO and other pharmacological iron chelators, has revealed similar binding potency (fig. 3). Both EGCG and the iron chelator M30 were shown by us to induce a significant downregulation of membrane-associated holoAPP level in the mouse hippocampus (fig. 4), SH-SY5Y and CHO cells expressing the APP 'Swedish' mutation (data not shown). This may have a direct influence on $A \beta$ levels and plaque formation, as shown in preliminary studies for $\mathrm{XH} 1$ [102]. Indeed, using a nucleation-dependent polymerization model, it has been shown that wine and green tea polyphenols are able to inhibit formation, extension and destabilization of $\beta$-amyloid fibrils [108].

Other potential beneficial effect of EGCG in AD may be related to our previous studies demonstrating the ability of EGCG to promote the non-amyloidogenic pathway, via a PKC-dependent activation of $\alpha$-secretase, thereby increasing $\operatorname{sAPP} \alpha$ [46]. sAPP $\alpha$ has been demonstrated to posses potent neuroprotective activities against excitotoxic and oxidative insults in various cellular models [109] and it was shown to protect against p53-mediated apoptosis [110]. Moreover, sAPP $\alpha$ promotes neurite outgrowth [111], regulates synaptogenesis [112] and exerts trophic effects on cerebral neurons in culture. As $\operatorname{SAPP} \alpha$ and A $\beta$ are formed by two mutually exclusive mechanisms, stimulation of the secretory processing of sAPP $\alpha$ might prevent the formation of the amyloidogenic $A \beta$. Thus, EGCG may influence $A \beta$ levels, either via translational inhibition of APP or by regulating APP processing. Finally, iron chelation by EGCG may ablate $\mathrm{Fe}^{3+}$-induced aggregation of hyperphosphorylated tau (PHF $\tau)$, the major constituent 
Fig. 4. Effect of EGCG and M30 on APP processing in mice hippocampus. Representative Western blots of levels of holoAPP in the membrane compartment, obtained from hippocampus of mice treated with EGCG (2 mg/kg) (A), or with M30 $(5 \mathrm{mg} / \mathrm{kg})$ (B) for 14 days detected with 22C11 antibody (directed to the to APP $\mathrm{N}$-terminus) or with a C-terminus APP antibody, respectively. Densitometric analysis is expressed as percent of the control, untreated animals after normalizing to the levels of $\beta$-actin. Data are expressed as the mean $\pm \operatorname{SEM}(\mathrm{n}=6$ mice in each group). $* * \mathrm{p}<0.03$ vs. control. Figure drawn using information from Levites et al. [46].
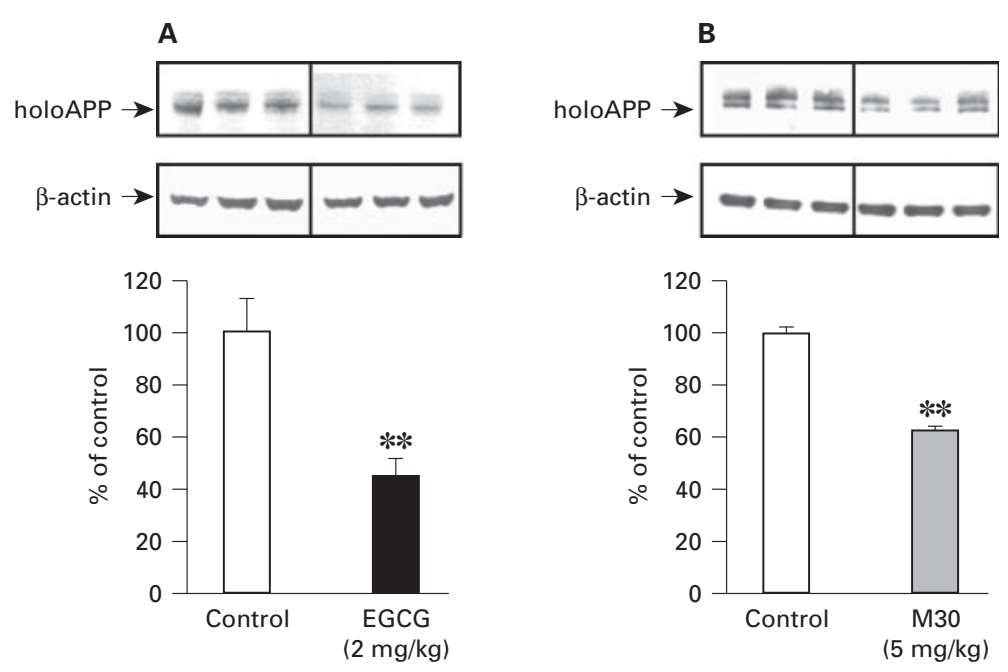

Fig. 5. Proposed schematic model for EGCG neuroprotective effect via regulation of APP processing and A $\beta$ formation. $\uparrow$ Increased levels/activity, $\downarrow$ decreased levels/activity. For full explanation, see text.

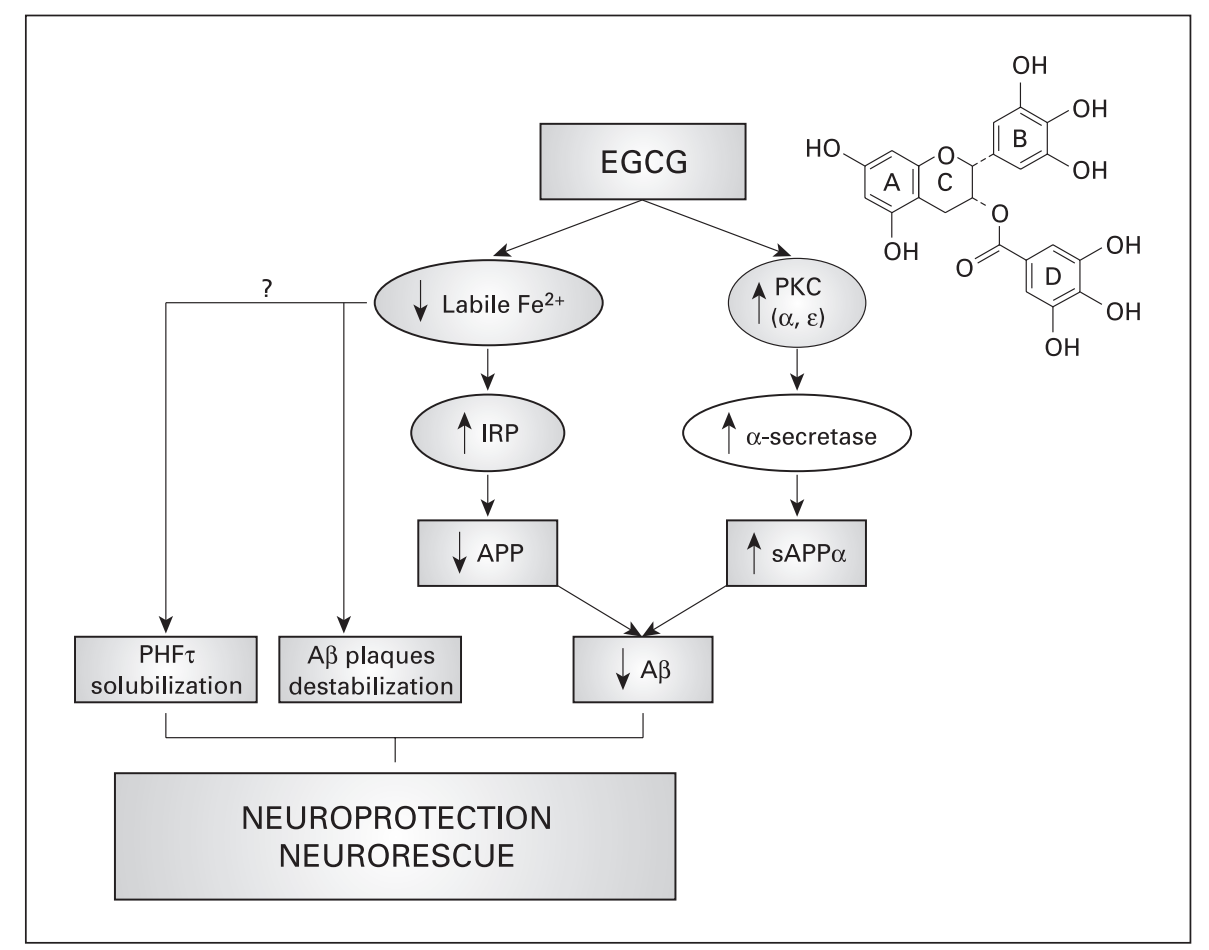

of neurofibrillary tangles in AD brains [113] (a descriptive explanation is depicted in fig. 5).

\section{Iron Chelation for PD}

Numerous studies have shown that there is a progressive accumulation of iron and ferritin in the SN pars com- pacta (pc) of PD patients [17, 27, 114]. Specifically, redox-active iron has been observed in the rim of Lewy body, the morphological hallmark of PD, also composed of lipids, aggregated $\alpha$-synuclein (concentrating in its peripheral halo) and ubiquitinated, hyperphosphorylated neurofilament proteins [115]. $\alpha$-Synuclein associated 


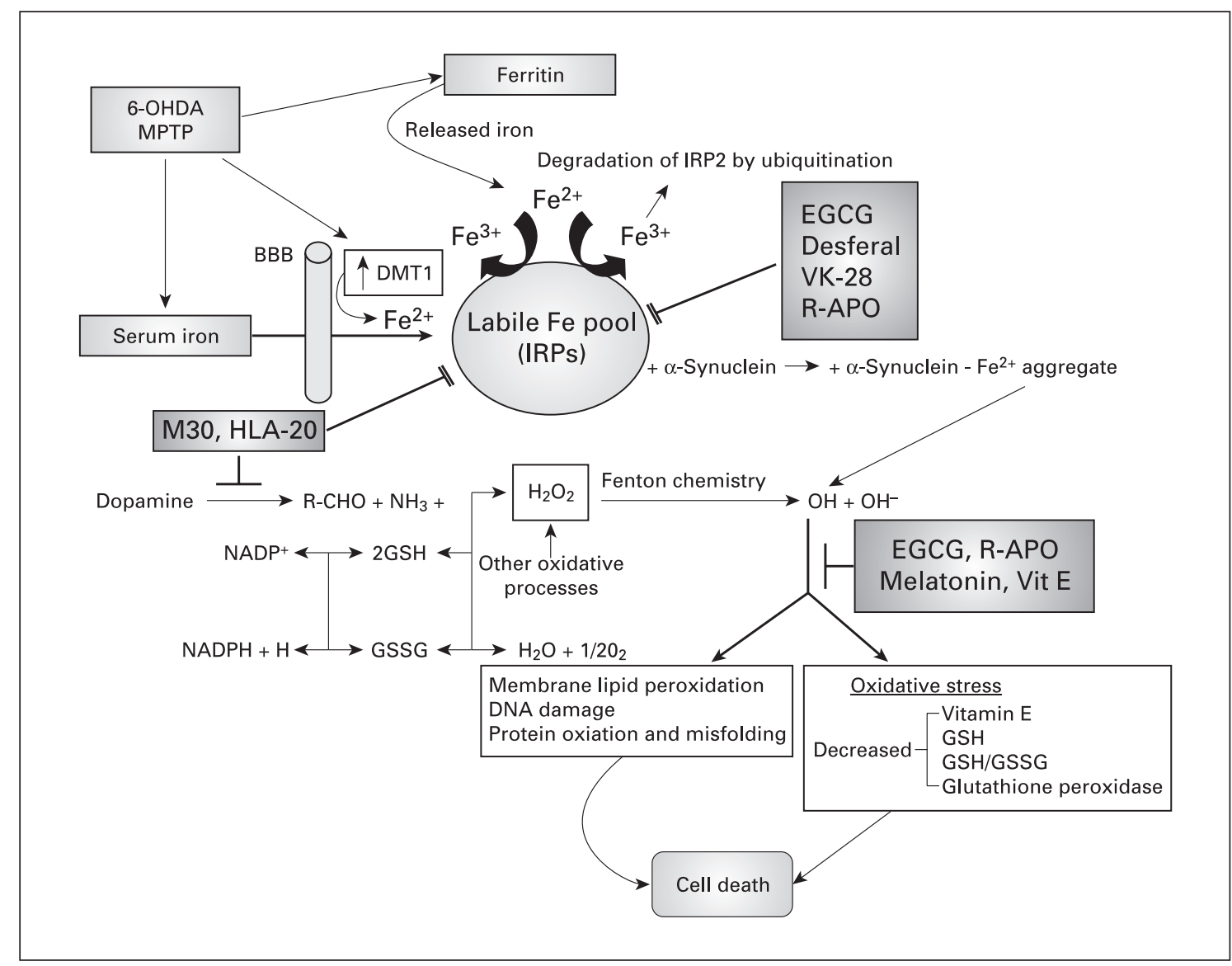

Fig. 6. Possible mechanism of neurotoxin-induced iron uptake, release and interaction with $\alpha$-synuclein resulting in OS initiated neurodegeneration and its prevention by iron-chelating/antioxidants. The mechanism by which 6-OHDA and MPTP induce increase of iron in substantia nigra pars compacta and within the melanin-containing neurons is not known. These neurotoxins may (a) activate the divalent metal transporter 1 (DMT1) which is responsible for iron transport into the brain across the cell membrane; (b) alter the blood-brain barrier (BBB), thereby allowing iron access to the brain; (c) induce release of iron from ferritin which enters the labile (redox-active) pool of iron. It is the labile pool of iron which can initiate the Fenton chemistry in response to the presence of hydrogen peroxide, thus generating the highly reactive hydroxyl radical $\left(\mathrm{OH}^{*}\right)$. The resultant effect is the depletion of cell-reduced glutathione (GHS), the rate-limiting cofactor of glutathione peroxidase, the main enzymatic pathway in the brain, to eliminate hydrogen peroxide. Labile pool of iron can also cause aggregation of $\alpha$-synuclein to the neurotoxic form, which can also generate $\mathrm{OH}^{*}$. The net effect is oxidative-stress-dependent damage to neuron antioxidant mechanism, membrane lipid peroxidation, demise of cell and mitochondrial membrane, protein misfolding and ultimate cell death. Neuroprotective agents that can be used to prevent iron-induced neurodegeneration include M30 and HLA20 (bifunctional iron chelator-MAO inhibitors); desferal, VK-28, R-APO (R-apomorphine) and EGCG (iron chelators); R-APO, EGCG, melatonin and Vit E (vitamin E) (radical scavengers). Sharp arrows indicate positive inputs, whereas blunt arrows are for inhibitory inputs. Reproduced, with minor modifications, from Youdim et al. [106]. with presynaptic membrane is not toxic; however, a number of recent studies [116-118] have shown that it forms toxic aggregates in the presence of iron and this is considered to contribute to the formation of Lewy body via OS, being one of its constituents.

Our recent high throughput gene expression study in the SNpc of Parkinsonian brains employing Affymetrix chip technology [29] has revealed a significant increase on the key iron and oxygen sensor EGLN1 gene coding for an isoform of 2-oxoglutarate-dependent dioxygenase hydroxylase (see previous section). Excessive production of EGLN1 hydroxylase in the SNpc may lead to a fall in IRP2 and subsequent decrease in transferrin receptor (TfR) mRNA and increase in ferritin levels, both subjected to positive and negative transcriptional regulation by IRP2, respectively $[119,120]$. Recent studies in knock- 
out mice for IRP2 have revealed accumulation of iron in the striatum with substantial bradykinesia and tremor [121].

Consistent with the pivotal role of iron in neurodegeneration is the finding that the iron chelator desferal prevents cytochrome $c$-induced- $\alpha$-synuclein aggregation and toxicity in vitro [122] and attenuates dopaminergic neurotoxicity in response to neurotoxins MPTP and 6-OHDA in vivo $[123,124]$. In line with the iron-chelating feature of EGCG, this polyphenol was shown to prevent $\alpha$-synuclein accumulation and to attenuate IRP2 depletion, in the SNpc of mice intoxicated with MPTP, when given orally for a period of 2 weeks [62]. This may be associated to our previous studies where green tea extract or EGCG prevented DA-containing neuron degeneration and tyrosine hydroxylase activity decrease [30]. In spite of the absence of clinical trials regarding tea polyphenols and PD, epidemiological studies have shown reduced risk of PD associated with consumption of 2 cups/day or more of tea [125] and a much lower prevalence of PD in Chinese population than in white people $[126,127]$.

Additional studies examining the effect of iron chelation, by either transgenic expression of the iron-binding protein, ferritin, or oral administration of the metal chelator clioquinol, have shown significant attenuation of MPTP-induced neurotoxicity [128]. These findings have now been substantiated with systemic injection of the brain-permeable iron chelator, $\mathrm{VK}-28$, to rats in response to 6-OHDA [104]. In line, nutritional iron deficiency pro- tects rats against kainate and 6-OHDA [129]. Figure 6 summarizes the mechanism of neurotoxin-induced iron uptake, release and interaction with $\alpha$-synuclein resulting in OS initiated neurodegeneration and its prevention by iron-chelating/antioxidant agents.

\section{Conclusions}

It is likely that syndromes such as $\mathrm{AD}$ and $\mathrm{PD}$ will require multiple- drug therapy to address the varied pathological aspects of the disease. Therefore, the use of compounds with poly-pharmacological activities or cocktail of drugs is a promising therapeutic approach for the treatment of neurodegenerative diseases. Indeed, a wealth of new data indicates that green tea catechins are being recognized as multifunctional compounds for neuroprotection. They act as radical scavengers, iron chelators and modulators of pro-survival genes, and PKC signaling pathway. The use of EGCG as a natural, non-toxic, lipophilic brain permeable neuroprotective drug is advocated for 'ironing out iron' from those brain areas where it preferentially accumulates in neurodegenerative diseases [106]. Thus, green tea catechins may have potential disease-modifying action. Future efforts in the understanding of the protective mechanism of action of these polyphenols should concentrate on deciphering the cellular targets affected by these compounds and other neuroprotectants.

\section{References}

-1 Butterfield D, Castegna A, Pocernich C, Drake J, Scapagnini G, Calabrese V: Nutritional approaches to combat oxidative stress in Alzheimer's disease. J Nutr Biochem 2002;13: 444.

- 2 Wang ZY, Huang MT, Lou YR, Xie JG, Reuhl KR, Newmark HL, Ho CT, Yang CS, Conney $\mathrm{AH}$ : Inhibitory effects of black tea, green tea, decaffeinated black tea, and decaffeinated green tea on ultraviolet $\mathrm{B}$ light-induced skin carcinogenesis in 7,12-dimethylbenz[a]anthra cene-initiated SKH-1 mice. Cancer Res 1994. 54:3428-3455.

3 Yang CS, Wang ZY: Tea and cancer. J Natl Cancer Inst 1993;85:1038-1049.

-4 Wiseman SA, Balentine DA, Frei B: Antioxidants in tea. Crit Rev Food Sci Nutr 1997;37: 705-718.

5 Higdon JV, Frei B: Tea catechins and polyphenols: health effects, metabolism, and antioxidant functions. Crit Rev Food Sci Nutr 2003; 43:89-143.
6 Jiang F, Dusting GJ: Natural phenolic compounds as cardiovascular therapeutics: Potential role of their anti-inflammatory effects. Curr Vasc Pharmacol 2003;1:135-156.

7 Guo Q, Zhao B, Shen S, Hou J, Hu J, Xin W: ESR study on the structure-antioxidant activity relationship of tea catechins and their epimers. Biochim Biophys Acta 1999;1427:13-23.

$>8$ Hider RC, Liu ZD, Khodr HH: Metal chelation of polyphenols. Methods Enzymol 2001; 335:190-203

9 Guo Q, Zhao B, Li M, Shen S, Xin W: Studies on protective mechanisms of four components of green tea polyphenols against lipid peroxidation in synaptosomes. Biochim Biophys Acta 1996;1304:210-222.

10 Kumamoto M, Sonda T, Nagayama K, Tabata $\mathrm{M}$ : Effects of $\mathrm{pH}$ and metal ions on antioxidative activities of catechins. Biosci Biotechnol Biochem 2001;65:126-132.
11 Grinberg LN, Newmark H, Kitrossky N, Rahamim E, Chevion M, Rachmilewitz EA: Protective effects of tea polyphenols against oxidative damage to red blood cells. Biochem Pharmacol 1997;54:973-978.

12 Mandel S, Weinreb O, Amit T, Youdim MBH: Cell signaling pathways in the neuroprotective actions of the green tea polyphenol (-)-epigallocatechin-3-gallate: implications for neurodegenerative diseases. J Neurochem 2004;88: 1555-1569.

13 Weinreb O, Mandel S, Amit T, Youdim MB: Neurological mechanisms of green tea polyphenols in Alzheimer's and Parkinson's diseases. J Nutr Biochem 2004;15:506-516.

-14 Suganuma M, Okabe S, Oniyama M, Tada Y, Ito $\mathrm{H}$, Fujiki $\mathrm{H}$ : Wide distribution of $\left[{ }^{3} \mathrm{H}\right](-)$ epigallocatechin gallate, a cancer preventive tea polyphenol, in mouse tissue. Carcinogenesis 1998;19:1771-1776. 
15 Nakagawa K, Miyazawa T: Absorption and distribution of tea catechin, (-)-epigallocatechin-3-gallate, in the rat. J Nutr Sci Vitaminol (Tokyo) 1997;43:679-684.

-16 Abd El Mohsen MM, Kuhnle G, Rechner AR, Schroeter H, Rose S, Jenner P, Rice-Evans CA: Uptake and metabolism of epicatechin and its access to the brain after oral ingestion. Free Rad Biol Med 2002;33:1693-1702.

$\checkmark 17$ Zecca L, Youdim MB, Riederer P, Connor JR, Crichton RR: Iron, brain ageing and neurodegenerative disorders. Nat Rev Neurosci 2004; 5:863-873.

18 Blum D, Torch S, Lambeng N, Nissou M, Benabid AL, Sadoul R, Verna JM: Molecular pathways involved in the neurotoxicity of 6-OHDA, dopamine and MPTP: Contribution to the apoptotic theory in Parkinson's disease. Prog Neurobiol 2001;65:135-172.

19 Linazasoro G: Neuroprotection in Parkinson's disease: Love story or mission impossible? Expert Rev Neurotherapeut 2002;2:403-416.

-20 McNaught KS, Belizaire R, Jenner P, Olanow CW, Isacson O: Selective loss of $20 \mathrm{~S}$ proteasome alpha-subunits in the substantia nigra pars compacta in Parkinson's disease. Neurosci Lett 2002;326:155-158.

21 Olanow CW, Youdim MB: Iron and neurodegeneration: Prospects for neuroprotection; in Olanow CW, Jenner P, Youdim MB (eds): Neurodegeneration and Neuroprotection in Parkinson's Disease. London, Academic Press, 1996, pp 55-69.

-22 Mandel S, Grunblatt E, Youdim MBH: cDNA microarray to study gene expression of dopaminergic neurodegeneration and neuroprotection in MPTP and 6-hydroxydopamine models: Implications for idiopathic Parkinson's disease. J Neural Transm Suppl 2000;60:117124.

23 Dauer W, Przedborski S: Parkinson's disease: Mechanisms and models. Neuron 2003;39: 889-909.

-24 Bonifati V, Rizzu P, van Baren MJ, Schaap O, Breedveld GJ, Krieger E, Dekker MC, Squitieri F, Ibanez P, Joosse M, van Dongen JW, Vanacore N, van Swieten JC, Brice A, Meco G van Duijn CM, Oostra BA, Heutink P: Mutations in the DJ-1 gene associated with autosomal recessive early-onset parkinsonism. Science 2003;299:256-259.

25 Valente EM, Abou-Sleiman PM, Caputo V, Muqit MM, Harvey K, Gispert S, Ali Z, Del Turco D, Bentivoglio AR, Healy DG, Albanese A, Nussbaum R, Gonzalez-Maldonado R, Deller T, Salvi S, Cortelli P, Gilks WP, Latchman DS, Harvey RJ, Dallapiccola B, Auburger G, Wood NW: Hereditary early-onset Parkinson's disease caused by mutations in PINK1. Science 2004;304:1158-1160.

26 Shults CW, Oakes D, Kieburtz K, Beal MF, Haas R, Plumb S, Juncos JL, Nutt J, Shoulson I, Carter J, Kompoliti K, Perlmutter JS, Reich S, Stern M, Watts RL, Kurlan R, Molho E, Harrison M, Lew M: Effects of coenzyme Q10 in early Parkinson disease: Evidence of slowing of the functional decline. Arch Neurol 2002; 59:1541-1550.
27 Riederer P, Sofic E, Rausch WD, Schmidt B, Reynolds GP, Jellinger K, Youdim $\mathrm{MBH}$ Transition metals, ferritin, glutathione, and ascorbic acid in parkinsonian brains. J Neurochem 1989;52:515-520.

28 Jenner P, Olanow CW: Oxidative stress and the pathogenesis of Parkinson's disease. Neurology 1996;47:S161-170.

29 Grunblatt E, Mandel S, Jacob-Hirsch J, Zeligson S, Amariglo N, Rechavi G, Li J, Ravid R, Roggendorf W, Riederer P, Youdim MB: Gene expression profiling of parkinsonian substantia nigra pars compacta: Alterations in ubiquitinproteasome, heat shock protein, iron and oxidative stress regulated proteins, cell adhesion/ cellular matrix and vesicle trafficking genes. $\mathrm{J}$ Neural Transm 2004;111:1543-1573.

30 Levites Y, Weinreb O, Maor G, Youdim MBH, Mandel S: Green tea polyphenol (-)-epigallocatechin-3-gallate prevents N-methyl-4-phenyl-1,2,3,6-tetrahydropyridine-induced dopaminergic neurodegeneration. J Neurochem 2001;78:1073-1082.

31 Komatsu M, Hiramatsu M: The efficacy of an antioxidant cocktail on lipid peroxide level and superoxide dismutase activity in aged rat brain and DNA damage in iron-induced epileptogenic foci. Toxicology 2000;148:143-148.

32 Pan T, Fei J, Zhou X, Jankovic J, Le W: Effects of green tea polyphenols on dopamine uptake and on $\mathrm{MPP}^{+}$-induced dopamine neuron injury. Life Sci 2003;72:1073-1083.

-33 Lu H, Meng X, Yang CS: Enzymology of methylation of tea catechins and inhibition of catechol-O-methyltransferase by (-)-epigallocatechin gallate. Drug Metab Dispos 2003;31: 572-579

34 Lee S, Suh S, Kim S: Protective effects of the green tea polyphenol (-)-epigallocatechin gallate against hippocampal neuronal damage after transient global ischemia in gerbils. Neurosci Lett 2000;287:191-194.

35 Lee H, Bae JH, Lee SR: Protective effect of green tea polyphenol EGCG against neuronal damage and brain edema after unilateral cerebral ischemia in gerbils. J Neurosci Res 2004; 77:892-900.

36 Suzuki M, Tabuchi M, Ikeda M, Umegaki K, Tomita T: Protective effects of green tea catechins on cerebral ischemic damage. Med Sci Monit 2004; 10:BR166-174.

37 Sutherland BA, Shaw OM, Clarkson AN, Jackson DM, Sammut IA, Appleton I: Neuroprotective effects of (-)-epigallocatechin gallate after hypoxia-ischemia-induced brain damage: novel mechanisms of action. Faseb J 2004

38 Townsend PA, Scarabelli TM, Davidson SM, Knight RA, Latchman DS, Stephanou A: STAT-1 interacts with p53 to enhance DNA damage-induced apoptosis. J Biol Chem 2004 279:5811-5820.

39 Aktas O, Prozorovski T, Smorodchenko A, Savaskan NE, Lauster R, Kloetzel PM, Infante-Duarte C, Brocke S, Zipp F: Green tea epigallocatechin-3-gallate mediates T cellular NFkappa $\mathrm{B}$ inhibition and exerts neuroprotection in autoimmune encephalomyelitis. J Immunol 2004; 173:5794-5800.
40 Schroeter H, Spencer JP, Rice-Evans C, Williams RJ: Flavonoids protect neurons from oxidized low-density-lipoprotein-induced apoptosis involving c-Jun N-terminal kinase (JNK), c-Jun and caspase-3. Biochem J 2001; 358:547-557.

41 Spencer JP, Schroeter H, Kuhnle G, Srai SK, Tyrrell RM, Hahn U, Rice-Evans C: Epicatechin and its in vivo metabolite, 3'-O-methyl epicatechin, protect human fibroblasts from oxidative-stress-induced cell death involving caspase-3 activation. Biochem J 2001;354:493500 .

42 Nobre Junior HV, Cunha GM, Maia FD, Oliveira RA, Moraes MO, Rao VS: Catechin attenuates 6-hydroxydopamine (6-OHDA)-induced cell death in primary cultures of mesencephalic cells. Comp Biochem Physiol [C] 2003; 136:175-180.

43 Mercer LD, Kelly BL, Horne MK, Beart PM: Dietary polyphenols protect dopamine neurons from oxidative insults and apoptosis: Investigations in primary rat mesencephalic cultures. Biochem Pharmacol 2005;69:339-345.

44 Levites Y, Amit T, Youdim MBH, Mandel S: Involvement of protein kinase $\mathrm{C}$ activation and cell survival/cell cycle genes in green tea polyphenol (-)-epigallocatechin-3-gallate neuroprotective action. J Biol Chem 2002;277: 30574-30580.

45 Choi YT, Jung CH, Lee SR, Bae JH, Baek WK, Suh MH, Park J, Park CW, Suh SI: The green tea polyphenol (-)-epigallocatechin gallate attenuates beta-amyloid-induced neurotoxicity in cultured hippocampal neurons. Life Sci 2001;70:603-614.

46 Levites Y, Amit T, Mandel S, Youdim MBH Neuroprotection and neurorescue against amyloid beta toxicity and PKC-dependent release of non-amyloidogenic soluble precusor protein by green tea polyphenol (-)-epigallocatechin-3-gallate. FASEB J 2003;17:952954

47 Reznichenko L, Amit T, Youdim MB, Mandel S: Green tea polyphenol (-)-epigallocatechin-3-gallate induces neurorescue of longterm serum-deprived PC12 cells and promotes neurite outgrowth. J Neurochem 2005;in press.

48 Weinreb O, Mandel S, Youdim MBH: cDNA gene expression profile homology of antioxidants and their anti-apoptotic and pro-apoptotic activities in human neuroblastoma cells. FASEB J 2003; 17:935-937.

49 Halliwell B: Vitamin C: antioxidant or pro-oxidant in vivo? Free Rad Res 1996;25:439-454.

50 Gassen M, Pinchasi B, Youdim MB: Apomorphine is a potent radical scavenger and protects cultured pheochromocytoma cells from 6OHDA and $\mathrm{H}_{2} \mathrm{O}_{2}$-induced cell death. Adv Pharmacol 1998;42:320-324.

51 Gassen M, Gross A, Youdim MB: Apomorphine enantiomers protect cultured pheochromocytoma (PC12) cells from oxidative stress induced by $\mathrm{H}_{2} \mathrm{O}_{2}$ and 6-hydroxydopamine. Mov Disord 1998; 13:242-248. 
52 Galati G, O'Brien PJ: Potential toxicity of flavonoids and other dietary phenolics: Significance for their chemopreventive and anticancer properties. Free Radic Biol Med 2004;37: 287-303.

-53 Wiseman S, Mulder T, Rietveld A: Tea flavonoids: Bioavailability in vivo and effects on cell signaling pathways in vitro. Antioxid Redox Signal 2001;3:1009-1021.

- 54 Durkin JP, Tremblay R, Chakravarthy B, Mealing G, Morley P, Small D, Song D: Evidence that the early loss of membrane protein kinase $\mathrm{C}$ is a necessary step in the excitatory amino acid-induced death of primary cortical neurons. J Neurochem 1997;68:1400-1412.

55 Maher P: How protein kinase C activation protects nerve cells from oxidative stress-induced cell death. J Neurosci 2001;21:2929-2938.

- 56 Vianna MR, Barros DM, Silva T, Choi H, Madche C, Rodrigues C, Medina JH, Izquierdo I: Pharmacological demonstration of the differential involvement of protein kinase $\mathrm{C}$ isoforms in short- and long-term memory formation and retrieval of one-trial avoidance in rats. Psychopharmacology (Berl) 2000;150: $77-84$.

-57 Lange-Asschenfeldt C, Raval AP, Dave KR, Mochly-Rosen D, Sick TJ, Perez-Pinzon MA: Epsilon protein kinase $\mathrm{C}$ mediated ischemic tolerance requires activation of the extracellular regulated kinase pathway in the organotypic hippocampal slice. J Cereb Blood Flow Metab 2004;24:636-645.

- 58 Cordey M, Gundimeda U, Gopalakrishna R, Pike CJ: Estrogen activates protein kinase $\mathrm{C}$ in neurons: Role in neuroprotection. J Neurochem 2003;84:1340-1348.

-59 Han YS, Zheng WH, Bastianetto S, Chabot JG, Quirion R: Neuroprotective effects of resveratrol against beta-amyloid-induced neurotoxicity in rat hippocampal neurons: involvement of protein kinase C. Br J Pharmacol 2004; 141: 997-1005.

60 Youdim MBH: Rasagiline: An anti-Parkinson drug with neuroprotective activity. Expert Rev Neurotherapeut 2003;3:737-749.

-61 Weinreb O, Bar-Am O, Amit T, Chillag-Talmor O, Youdim MB: Neuroprotection via prosurvival protein kinase $\mathrm{C}$ isoforms associated with Bcl-2 family members. FASEB J 2004; 18 : 1471-1473.

-62 Mandel S, Maor G, Youdim MBH: Iron and alpha-synuclein in the substantia Nigra of MPTP-treated mice: Effect of neuroprotective drugs R-apomorphine and green tea polyphenol (-)-epigallocatechin-3-gallate. J Mol Neurosci 2004;24:401-416.

-63 Ruvolo PP, Deng X, Carr BK, May WS: A functional role for mitochondrial protein kinase Calpha in Bcl2 phosphorylation and suppression of apoptosis. J Biol Chem 1998;273: 25436-25442.

-64 Jiffar T, Kurinna S, Suck G, Carlson-Bremer D, Ricciardi MR, Konopleva M, Andreeff M, Ruvolo PP: PKC alpha mediates chemoresistance in acute lymphoblastic leukemia through effects on Bcl2 phosphorylation. Leukemia 2004; 18:505-512.
65 Kim SY, Ahn BH, Kim J, Bae YS, Kwak JY, Min G, Kwon TK, Chang JS, Lee YH, Yoon $\mathrm{SH}$, Min do S: Phospholipase C, protein kinase $\mathrm{C}, \mathrm{Ca}^{2+} /$ calmodulin-dependent protein kinase II, and redox state are involved in epigallocatechin gallate-induced phospholipase $\mathrm{D}$ activation in human astroglioma cells. Eur J Biochem 2004;271:3470-3480.

66 Kumazawa S, Kajiya K, Naito A, Saito H, Tuzi S, Tanio M, Suzuki M, Nanjo F, Suzuki E, Nakayama T: Direct evidence of interaction of a green tea polyphenol, epigallocatechin gallate, with lipid bilayers by solid-state nuclear magnetic resonance. Biosci Biotechnol Biochem 2004;68:1743-1747.

67 Saito H, Tabeta R, Kodama M, Nagata C, Sato $\mathrm{Y}$ : Direct evidence of incorporation of 12-O[20-2H1] tetradecanoylphorbol-13-acetate into artificial membranes as determined by deuterium magnetic resonance. Cancer Lett 1984; 22:65-69.

68 Gary DS, Milhavet O, Camandola S, Mattson MP: Essential role for integrin linked kinase in Akt-mediated integrin survival signaling in hippocampal neurons. J Neurochem 2003;84: 878-890.

69 Kermer P, Klocker N, Labes M, Bahr M: Insulin-like growth factor-I protects axotomized rat retinal ganglion cells from secondary death via PI3-K-dependent Akt phosphorylation and inhibition of caspase-3 in vivo. J Neurosci 2000; 20:2-8.

-70 Singer CA, Figueroa-Masot XA, Batchelor RH, Dorsa DM: The mitogen-activated protein kinase pathway mediates estrogen neuroprotection after glutamate toxicity in primary cortical neurons. J Neurosci 1999; 19:24552463.

71 Schroeter H, Boyd C, Spencer JP, Williams RJ, Cadenas E, Rice-Evans C: MAPK signaling in neurodegeneration: Influences of flavonoids and of nitric oxide. Neurobiol Aging 2002;23: 861-880.

72 Vaudry D, Stork PJ, Lazarovici P, Eiden LE: Signaling pathways for PC12 cell differentiation: Making the right connections. Science 2002;296:1648-1649.

73 Harris CA, Deshmukh M, Tsui-Pierchala B, Maroney AC, Johnson EM Jr: Inhibition of the c-Jun N-terminal kinase signaling pathway by the mixed lineage kinase inhibitor CEP-1347 (KT7515) preserves metabolism and growth of trophic factor-deprived neurons. J Neurosci 2002;22:103-113.

74 Alessandrini A, Namura S, Moskowitz MA, Bonventre JV: MEK1 protein kinase inhibition protects against damage resulting from focal cerebral ischemia. Proc Natl Acad Sci USA 1999:96:12866-12869.

75 Yun HY, Gonzalez-Zulueta M, Dawson VL, Dawson TM: Nitric oxide mediates N-methyl$D$-aspartate receptor-induced activation of p21ras. Proc Natl Acad Sci USA 1998;95: 5773-5778.
76 Yu R, Jiao JJ, Duh JL, Gudehithlu K, Tan TH, Kong AN: Activation of mitogen-activated protein kinases by green tea polyphenols: Potential signaling pathways in the regulation of antioxidant-responsive element-mediated phase II enzyme gene expression. Carcinogenesis 1997; 18:451-456.

77 Chen C, Yu R, Owuor ED, Kong AN: Activation of antioxidant-response element (ARE), mitogen-activated protein kinases (MAPKs) and caspases by major green tea polyphenol components during cell survival and death. Arch Pharm Res 2000;23:605-612.

78 Owuor ED, Kong AN: Antioxidants and oxidants regulated signal transduction pathways. Biochem Pharmacol 2002;64:765-770.

79 Chung JH, Han JH, Hwang EJ, Seo JY, Cho KH, Kim KH, Youn JI, Eun HC: Dual mechanisms of green tea extract-induced cell survival in human epidermal keratinocytes. FASEB J 2003; 17:1913-1915

80 Lorenz M, Wessler S, Follmann E, Michaelis W, Dusterhoft T, Baumann G, Stangl K, Stangl V: A constituent of green tea, epigallocatechin-3-gallate, activates endothelial nitric oxide synthase by a PI3K-, PKA-, and Akt-dependent pathway, and leads to endothelial-dependent vasorelaxation. J Biol Chem 2003.

-81 Tedeschi E, Menegazzi M, Yao Y, Suzuki H, Forstermann U, Kleinert H: Green tea inhibits human inducible nitric-oxide synthase expression by down-regulating signal transducer and activator of transcription-1alpha activation. Mol Pharmacol 2004;65:111-120.

82 Bernardi P, Petronilli V, Di Lisa F, Forte M: A mitochondrial perspective on cell death. Trends Biochem Sci 2001;26:112-117.

83 Cory S, Adams JM: The Bcl2 family: Regulators of the cellular life-or-death switch. Nat Rev Cancer 2002;2:647-656.

84 Merry DE, Korsmeyer SJ: Bcl-2 gene family in the nervous system. Annu Rev Neurosci 1997; 20:245-267.

85 DeFeudis FV, Drieu K: Ginkgo biloba extract (EGb 761) and CNS functions: Basic studies and clinical applications. Curr Drug Targets 2000;1:25-58.

86 Ishige K, Schubert D, Sagara Y: Flavonoids protect neuronal cells from oxidative stress by three distinct mechanisms. Free Radic Biol Med 2001;30:433-446.

- 87 Lee JH, Song DK, Jung CH, Shin DH, Park J, Kwon TK, Jang BC, Mun KC, Kim SP, Suh SI, Bae JH: (-)-Epigallocatechin gallate attenuates glutamate-induced cytotoxicity via intracellular $\mathrm{Ca}$ modulation in PC12 cells. Clin Exp Pharmacol Physiol 2004;31:530-536.

88 Bush AI: The metallobiology of Alzheimer's disease. Trends Neurosci 2003;26:207-214.

89 Atwood CS, Obrenovich ME, Liu T, Chan H, Perry G, Smith MA, Martins RN: Amyloidbeta: A chameleon walking in two worlds: A review of the trophic and toxic properties of amyloid-beta. Brain Res Brain Res Rev 2003; 43:1-16. 
90 Rogers JT, Randall JD, Cahill CM, Eder PS, Huang X, Gunshin H, Leiter L, McPhee J, Sarang SS, Utsuki T, Greig NH, Lahiri DK, Tanzi RE, Bush AI, Giordano T, Gullans SR: An iron-responsive element type II in the 5'untranslated region of the Alzheimer's amyloid precursor protein transcript. J Biol Chem 2002;277:45518-45528.

-91 Sharp FR, Bernaudin M: HIF1 and oxygen sensing in the brain. Nat Rev Neurosci 2004; 5:437-448.

\$2 Lee JW, Bae SH, Jeong JW, Kim SH, Kim KW: Hypoxia-inducible factor (HIF-1)alpha: Its protein stability and biological functions. Exp Mol Med 2004;36:1-12.

-93 Jaakkola P, Mole DR, Tian YM, Wilson MI, Gielbert J, Gaskell SJ, Kriegsheim A, Hebestreit HF, Mukherji M, Schofield CJ, Maxwell PH, Pugh CW, Ratcliffe PJ: Targeting of HIF-alpha to the von Hippel-Lindau ubiquitylation complex by $\mathrm{O}_{2}$-regulated prolyl hydroxylation. Science 2001;292:468-472.

94 Minchenko O, Opentanova I, Caro J: Hypoxic regulation of the 6-phosphofructo-2-kinase/fructose-2,6-bisphosphatase gene family (PFKFB-1-4) expression in vivo. FEBS Lett 2003;554:264-270.

95 Hanson ES, Leibold EA: Regulation of the iron regulatory proteins by reactive nitrogen and oxygen species. Gene Expr 1999; 7:367376.

96 Wang J, Chen G, Muckenthaler M, Galy B, Hentze MW, Pantopoulos K: Iron-mediated degradation of IRP2, an unexpected pathway involving a 2-oxoglutarate-dependent oxygenase activity. Mol Cell Biol 2004;24:954965.

-97 Crapper McLachlan DR, Dalton AJ, Kruck TP, Bell MY, Smith WL, Kalow W, Andrews DF: Intramuscular desferrioxamine in patients with Alzheimer's disease. Lancet 1991; 337:1304-1308.

98 Ritchie CW, Bush AI, Mackinnon A, Macfarlane S, Mastwyk M, MacGregor L, Kiers L, Cherny R, Li QX, Tammer A, Carrington D, Mavros C, Volitakis I, Xilinas M, Ames D, Davis S, Beyreuther K, Tanzi RE, Masters CL: Metal-protein attenuation with iodochlorhydroxyquin (clioquinol) targeting a beta amyloid deposition and toxicity in Alzheimer disease: A pilot phase 2 clinical trial. Arch Neurol 2003;60:1685-1691.

$\$ 99$ Meade TW: Subacute myelo-optic neuropathy and clioquinol: An epidemiological casehistory for diagnosis. Br J Prev Soc Med 1975; 29:157-169.

100 Baum L, Ng A: Curcumin interaction with copper and iron suggests one possible mechanism of action in Alzheimer's disease animal models. J Alzheimers Dis 2004;6:367-377; discussion 443-369.

-101 Lim GP, Chu T, Yang F, Beech W, Frautschy SA, Cole GM: The curry spice curcumin reduces oxidative damage and amyloid pathology in an Alzheimer transgenic mouse. J Neurosci 2001;21:8370-8377.
02 Dedeoglu A, Cormier K, Payton S, Tseitlin KA, Kremsky JN, Lai L, Li X, Moir RD, Tanzi RE, Bush AI, Kowall NW, Rogers JT, Huang X: Preliminary studies of a novel bifunctional metal chelator targeting Alzheimer's amyloidogenesis. Exp Gerontol 2004;39: 1641-1649.

103 Youdim MB, Fridkin M, Zheng H: Bifunctional drug derivatives of MAO-B inhibitor rasagiline and iron chelator VK-28 as a more effective approach to treatment of brain ageing and ageing neurodegenerative diseases. Mech Age Dev 2005;126:317-326.

104 Shachar DB, Kahana N, Kampel V, Warshawsky A, Youdim MB: Neuroprotection by a novel brain permeable iron chelator, VK28 , against 6-hydroxydopamine lesion in rats. Neuropharmacology 2004;46:254-263.

105 Youdim MB, Fridkin M, Zheng H: Novel bifunctional drugs targeting monoamine oxidase inhibition and iron chelation as an approach to neuroprotection in Parkinson's disease and other neurodegenerative diseases. J Neural Transm 2004;111:1455-1471.

106 Youdim MBH, Buccafusco JJ: Multi-functional drugs for various CNS targets in the treatment of neurodegenerative disorders. Trends Pharmacol Sci 2005;26:27-35.

107 Zheng H, Weiner LM, Bar-Am O, Epsztejn S, Cabantchik ZI, Warshawsky A, Youdim MB, Fridkin M: Design, synthesis, and evaluation of novel bifunctional iron-chelators as potential agents for neuroprotection in Alzheimer's, Parkinson's, and other neurodegenerative diseases. Bioorg Med Chem 2005;13: 773-783.

108 Ono K, Yoshiike Y, Takashima A, Hasegawa K, Naiki H, Yamada M: Potent anti-amyloidogenic and fibril-destabilizing effects of polyphenols in vitro: Implications for the prevention and therapeutics of Alzheimer's disease. J Neurochem 2003;87:172-181.

109 Mattson MP, Barger SW, Furukawa K, Bruce AJ, Wyss-Coray T, Mark RJ, Mucke L: Cellular signaling roles of TGF beta, TNF alpha and beta APP in brain injury responses and Alzheimer's disease. Brain Res Rev 1997;23: 47-61.

110 Xu X, Yang D, Wyss-Coray T, Yan J, Gan L, Sun Y, Mucke L: Wild-type but not Alzheimer-mutant amyloid precursor protein confers resistance against p53-mediated apoptosis. Proc Natl Acad Sci USA 1999;96: 7547-7552.

111 Small DH, Nurcombe V, Reed G, Clarris H, Moir R, Beyreuther K, Masters CL: A heparin-binding domain in the amyloid protein precursor of Alzheimer's disease is involved in the regulation of neurite outgrowth. J Neurosci 1994; 14:2117-2127.

112 Morimoto T, Ohsawa I, Takamura C, Ishiguro M, Kohsaka S: Involvement of amyloid precursor protein in functional synapse formation in cultured hippocampal neurons. J Neurosci Res 1998;51:185-195.
113 Yamamoto A, Shin RW, Hasegawa K, Naiki H, Sato H, Yoshimasu F, Kitamoto T: Iron (III) induces aggregation of hyperphosphorylated tau and its reduction to iron (II) reverses the aggregation: implications in the formation of neurofibrillary tangles of Alzheimer's disease. J Neurochem 2002;82:1137-1147.

114 Gerlach M, Ben-Shachar D, Riederer P, Youdim MB: Altered brain metabolism of iron as a cause of neurodegenerative diseases? J Neurochem 1994;63:793-807.

115 Jellinger KA: Neuropathological spectrum of synucleinopathies. Mov Disord 2003;18 (suppl 6):2-12.

116 Turnbull S, Tabner BJ, El-Agnaf OM, Moore S, Davies Y, Allsop D: Alpha-Synuclein implicated in Parkinson's disease catalyses the formation of hydrogen peroxide in vitro. Free Radic Biol Med 2001;30:1163-1170.

117 Ostrerova-Golts N, Petrucelli L, Hardy J, Lee JM, Farer M, Wolozin B: The A53T alphasynuclein mutation increases iron-dependent aggregation and toxicity. J Neurosci 2000;20: 6048-6054.

118 Ebadi M, Govitrapong P, Sharma S, Muralikrishnan D, Shavali S, Pellett L, Schafer R, Albano C, Eken J: Ubiquinone (coenzyme q10) and mitochondria in oxidative stress of Parkinson's disease. Biol Signals Recept 2001;10:224-253.

119 Ponka P: Hereditary causes of disturbed iron homeostasis in the central nervous system. Ann NY Acad Sci 2004; 1012:267-281.

120 Meyron-Holtz EG, Ghosh MC, Iwai K, LaVaute T, Brazzolotto X, Berger UV, Land W, Ollivierre-Wilson H, Grinberg A, Love P, Rouault TA: Genetic ablations of iron regulatory proteins 1 and 2 reveal why iron regulatory protein 2 dominates iron homeostasis. EMBO J 2004;23:386-395.

121 LaVaute T, Smith S, Cooperman S, Iwai K, Land W, Meyron-Holtz E, Drake SK, Miller G, Abu-Asab M, Tsokos M, Switzer R 3rd, Grinberg A, Love P, Tresser N, Rouault TA: Targeted deletion of the gene encoding iron regulatory protein- 2 causes misregulation of iron metabolism and neurodegenerative disease in mice. Nat Genet 2001;27:209-214.

122 Hashimoto M, Takeda A, Hsu LJ, Takenouchi T, Masliah E: Role of cytochrome $\mathrm{c}$ as a stimulator of alpha-synuclein aggregation in Lewy body disease. J Biol Chem 1999;274: 28849-28852.

123 Ben-Shachar D, Eshel G, Finberg JP, Youdim MB: The iron chelator desferrioxamine (Desferal) retards 6-hydroxydopamine-induced degeneration of nigrostriatal dopamine neurons. J Neurochem 1991;56:1441-1444.

124 Lan J, Jiang DH: Desferrioxamine and vitamin E protect against iron and MPTP-induced neurodegeneration in mice. J Neural Transm (Budapest) 1997;104:469-481. 
125 Checkoway H, Powers K, Smith-Weller T, 127 Zhang ZX, Roman GC: Worldwide occurFranklin GM, Longstreth WT Jr, Swanson PD: Parkinson's disease risks associated with cigarette smoking, alcohol consumption, and caffeine intake. Am J Epidemiol 2002;155: 732-738.

126 Li SC, Schoenberg BS, Wang CC, Cheng XM, Rui DY, Bolis CL, Schoenberg DG: A prevalence survey of Parkinson's disease and other movement disorders in the People's Republic of China. Arch Neurol 1985;42:655-657. rence of Parkinson's disease: An updated review. Neuroepidemiology 1993;12:195-208.

128 Kaur D, Yantiri F, Rajagopalan S, Kumar J, Mo JQ, Boonplueang R, Viswanath V, Jacobs R, Yang L, Beal MF, DiMonte D, Volitaskis I, Ellerby L, Cherny RA, Bush AI, Andersen JK: Genetic or pharmacological iron chelation prevents MPTP-induced neurotoxicity in vivo: A novel therapy for Parkinson's disease. Neuron 2003;37:899-909.
129 Shoham S, Youdim MB: Nutritional iron deprivation attenuates kainate-induced neurotoxicity in rats: implications for involvement of iron in neurodegeneration. Ann NY Acad Sci 2004;1012:94-114. 